International Journal of Instruction e-ISSN: 1308-1470 • www.e-iji.net

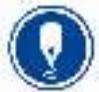

July $2021 \bullet$ Vol.14, No.3

p-ISSN: 1694-609X

pp. 583-596

Article submission code:

20200722172217

Received: 22/07/2020

Revision: 06/01/2021
Accepted: 29/01/2021

OnlineFirst: 05/06/2021

\title{
Is there a Split between Adult Educator's Educational Philosophy in Learning and Teaching Process?
}

\section{Genovefa Papadima}

Dr., University of Macedonia, Greece, gpapadima@uom.edu.gr

This paper aims to highlight a) the necessity of linking the educational philosophy with practice by presenting educational philosophical theories of the reference field, i.e., adult education, b) the prevailing educational philosophies in active adult educators and c) the possibility of the co-existence of two or more educational philosophies in the field of adult education, in relation to two parameters: education/learning and teaching process. Its contribution is to highlight the need for the trainer to be aware of the educational philosophy adopted in different parts of education such as the learning and teaching process. The research tool is the questionnaire by Lorraine Zinn, "Philosophy of Adult Education" (PAEI, 1983). The PAEI questionnaire by Zinn aspires to highlight the personality of the educator and investigate their critical awareness, the possibility of adopting alternative approaches in the planning of educational programs and teaching methodology and the realizability of the educator's broader evaluative goals.

Keywords: adult educator, educational philosophy, learning, PAEI, teaching

\section{INTRODUCTION}

The adult education is a particularly complex and multifaceted field because it is addressed to adult learners who have different needs, different experiences, different expectations and their own personal way of learning (Apps, 1973 / Jarvis 1985). According to Papanaoum (1994), the responsibility lies primarily with the educator, whose role is extremely demanding in coordinating the whole educational / learning process and its success.

In fact, this demanding role offers relative autonomy to those who practice it, but makes difficult any attempt to analyze it theoretically (Jarvis, Griffin, 2003). At this point comes the need for each adult educator to identify his own educational philosophy, because the ideal relationship between theory and practice is symbiotic (Papadima, 2021). Therefore, theory and practice are part of a unique reality and they cannot be separated (McKenzie, 1985). McKenzie's phrase (1985, p.212) illustrates the necessity of coexistence between theory and practice. He quotes that: "The theoretician who turns away from practice becomes an isolated ivory tower and on the other the professional, who is not fed up with the theoretical reflection, ultimately ends up in a shallow amateur". 
According to Kosivaki (2003), the theory constitutes the action. She mentions that the adult educator's teaching effectiveness is a synthesis of: a) his professional skills, and b) his theoretical knowledge. So, is it not reasonable for anyone who is involved in educational activities at any level of education to have set a goal, to know the teaching methods and the prevailing learning situation? However, it should be noticed that although the teaching practice precedes the theory, however, the good teaching practices are based on a valid theory (Kumar, 2012).

Therefore, according to Papadima (2021), it is immaterial, if the adult educator chooses and implements the principles of a specific educational philosophy. The important thing is that his teaching practice is based on a valid educational theory that he has consciously or unconsciously chosen (Bergevin, 1967). If the adult educator uses these theoretical bases, he is able to re-examine both how he behaved with his trainees but also what training methods he used in the past. This happens because he challenges his own beliefs and he is open mind to develop himself (Papadima, 2021). Consequently, it is obvious that adult education like any other level of education must have a theoretical base and it is not something fluid (Merriam \& Brockett, 1997).

At the same time, it should be noticed, as Zinn (1983) argues, that theory is insufficient to answer and solve every question that arises as the contribution of the educational philosophy adopted by an adult educator is never complete but it is constantly evolving and transforming, since it is directly dependent on its practical application. In order to answer the question: "how educational philosophy contributes?", it is equally important to answer a series of other sub-questions. These sub-questions regard to the purpose of education and learning, to the teaching process, but also to the socio-cultural and cultural context of each philosophy as well as to the personal educational philosophy that the learners themselves may have.

\section{Literature review}

\section{Educational philosophies}

The literature review begins with the presentation of the five philosophical theories: the liberalism, the behaviorism, the humanism, the progressivism and the radical theory, as Zinn (1983) categorized them in the Philosophy of Adult Education Inventory (PAEI). The Philosophy of Adult Education Inventory (PAEI) was designed by Zinn to define the philosophy of adult educators. Indeed, Zinn herself (1983, p. 7) states that "the conscious application of the principles of a philosophical theory in the field of adult education is particularly important as it helps to clarify the meaning, to organize knowledge and to discover the basic conditions or assumptions underlying adult education". Merriam (1986), however, identifies the key obstacle that exists is that adult educators, are governed or bound by a narrow institutional framework. Cervero (1988) reinforces this point of reinforce. He refers to the complexity, variety and lack of time of trainers to reflect on the philosophical background of the practices they employ in the educational process (Cervero, 1988). Also, Rodgers (1980) argues that action without reference to its theoretical context remains pure practice. Consequently, due to the necessity of linking theory and practice, the following five philosophical theories falling within the field of adult education will be presented: 


\section{Liberalism}

The purpose of this philosophical theory is to develop intellectual powers of the of the mind; to make a person literate in the broadest sense-intellectually, morally, spiritually, aesthetically (Broudy \& Palmer, 1965). The learning process is an end in itself and it should be holistic. Basic principle is the freedom of individuals to determine their own lives and the cultivation of their minds, with emphasis on understanding knowledge rather than on simply conquering it (Jarvis, 2005). The adult educator is the one who directs the learning process, he is the transmitter of knowledge, he is the authority (Elias \& Merriam, 1995). Liberals believed that theoretical education was more valuable than vocational training (Jarvis, 2005). Therefore, the curriculum should include timeless virtues and rational subjects (Van Doren, 1943). According to Jarvis, Holford \& Griffin (2003) dialectics, lectures, critical reading and discussion as well as reflection are the main teaching methods.

\section{Behaviorism}

Behaviorism emphasizes the importance of the environment for shaping good behavior. The purpose of this philosophy is to change or modify the behavior of the learner and focus solely on objectively observable behaviors (Zandavian, 2009). Learning is shaped by repetition and reinforcement as the learner responds to specific stimuli (Jerling, 1996). The adult educator has a guiding and controlling role, predicting the learning outcomes of the learner, who in turn assumes an active role in learning by receiving appropriate feedback (Gagné \& Medsker, 1996). This teacher-centered philosophical theory uses feedback and empowerment as teaching techniques to respond to specific stimuli (Skinner, 1976 / Phillips \& Soltis, 1991).

\section{Progressivism}

This educational philosophy is based on the principle that education is a social need. Its purpose is to transmit culture and social structure (Elias \& Merriam, 1995). It stresses the relationship between education and society, builds on and adapts to learners' experiences, as it argues that the learner learns best when dealing with his own interests, meeting his own personal needs, and it views education as an instrument of social action and change (Gutek, 2004). Dewey (1956), the major proponent of this philosophy, argues that learning is achieved by doing, while the role of the adult educator is to stimulate, instigate and evaluate the learning process by organizing it through educational experiences. Teaching methods used in this philosophy include problem solving, the scientific method, and cooperative learning (Boone et al, 2002).

\section{Humanism}

Humanism as philosophical theory is directly linked to existentialism and humanistic psychology. The key concepts emphasized are individual freedom, autonomy, confidence and self-efficacy. The ideal of personality, not of performance, is important, as the goal is self-fulfillment and self-directedness (Merriam \& Brockett, 1997). Consequently, learning is a creative and transformative affair that aims at the soul and personality of learner (Elias \& Merriam, 1995). The goal is to gain an understanding of both ourselves and our position in society. Thus, according to this particular student- 
centered theory, the learner, who is the center of the learning process and responsible for the subject and method of learning, is gradually led to knowledge. On the contrary the adult educator facilitates cooperation and communication through group dynamics (Conti, 2007 / Elias \& Merriam, 1995).

\section{Radical theory/constructivism}

Radical theory / constructivism, with emphasis on the coupling of education and political action, views education as a means of social and political change and criticizes traditional authoritarian and teacher-centered education (Fosnot, 1996 / Schunk, 1996).

Glasersferd (1984, 1987, 1989, 1995) states that education must be liberating, interactive and it has to aim at eliminating all forms of oppression and false forms of consciousness. Its purpose is to change society fundamentally, politically and economically. The adult educator facilitates the learner through interactive discussion anh he helps her/ him to learn. This process, according to this theory, is the realization of one's own life (Glasersferd, 1995). One particular case is constructivism which is based on the view that knowledge is constructed by the learner himself and is based on his previous knowledge and experiences (learning how to learn) (Sener, 1997 / Gergen, 1994). One particular case is constructivism which is based on the view that knowledge is constructed by the learner himself and it is based on his previous knowledge and experiences (learning how to learn) (Sener, 1997/ Gergen, 1994).

\section{METHOD}

\section{Purpose and Objectives}

The purpose of the present research was to correlate the embracing educational philosophy in learning process with the embracing educational philosophy in learning process. The objectives were to determine: 1) the prevailing personal educational philosophy of active adult educators in Greece, 2) the prevailing personal educational philosophy in learning process of active adult educators in Greece, 3) the prevailing personal educational philosophy in teaching process of active adult educators in Greece.

\section{Participants}

Participants are 399 adult educators who are selected by random sampling. The participants are active adult educators of any specialty at the Lifelong Learning Centers, affiliated with the Youth and Lifelong Learning Foundation (INEDIVIM). This sample of adult trainers was selected because the educators in a Lifelong Learning Center have to qualify for the post. In addition to the higher education degree that must be relevant to their subject matter, they must have and other qualifications related to adult education. These qualifications are a postgraduate or doctoral degree in adult education, his training by public or private providers as well as his teaching experience in adult education (Law No: 3879/2010, Greek Government Gazette No 163/A/ 21-9-2010).

Furthermore, each participant had to answer 2 additional demographics, his/her gender and his/her educational level (1st degree, 2nd degree, postgraduate degree, doctoral degree). Specifically, from 399 adult educators, $258(64,8 \%)$ are women and 141 $(35,2 \%)$ are men. With regard to the highest level of education, $238(59.6 \%)$ educators 
have received one bachelor's degree related to their teaching object, $42(10.5 \%)$ educators have received two bachelor's degrees, 107 (26.8\%) are holders a master's degree and $12(3 \%)$ are doctorate holders.

\section{Instrument}

To collect the research data, was used, Philosophy of Adult Education Inventory originally developed and documented by Lorraine M. Zinn (1983), which was adapted in Greek. Specifically, the PAEI can serve as a self-evaluating tool and systematizes the participants in categories correlative to the five, previously mentioned, educational philosophies: the liberalism, the behaviorism, the humanism, the progressivism and the radical theory. It has fifteen incomplete sentences, each one resulting in five different choices reflecting the philosophical theories. For each incomplete sentence, there is a Likert scale of 1 (strongly disagree) to 7 (strongly agree). It becomes clear from the beginning that there are no right or wrong answers and the participant chooses the answer that he considers to be closer to him. Zinn (1991) even states that each educator may have (as is usually the case) a primary philosophical orientation, but this does not preclude the fact that he embraces two philosophical currents, which does not make the questionnaire an absolute meter.

The main reason for choosing this questionnaire for this research is that it overshadows other questionnaires in the field, such as ATLAS, PALS, PHIL because systematizes its questions in individual processes such as learning (questions: 2, 3, 4, 5) and teaching (questions: 1, 8, 10, 13).

The questionnaire was tested by in a variety of ways and I concluded that it was reliable and valid. The coefficient Cronbach alpha and one-dimensionality testing, which was performed using Principal Component Analysis, were used to assess the reliability and validity in Greek. In addition, for the suitability of data were calculated and controlled by Kaiser-Meyer-Olkin Measure and Bartlett's test of sphericity. More specifically, the Cronbach's alpha is 0.911 for questions about learning and it is 0.874 for questions about teaching, so it confirms the reliability. Also, the values of Kaiser-Meyer-Olkin Measure (KMO), which are 0.853 for questions about learning and 0.812 for questions about teaching ensure that data are suitable (Papadima, 2017).

\section{Procedures}

The questionnaire's completion was done by self-filling. Prior to the questionnaires being distributed to the trainer population, the required entry permits were secured, following the approval of my request to conduct research in the Program: "Lifelong Learning Centers - National Intervention Programs \& Local Area Programs AP 7 \& AP 8". The questionnaires were sent to the trainers by the Education, Development and Quality Assurance Officers of the different municipalities that belonged.

\section{Analysis of Data}

A descriptive research survey methodology and a correlational design were used in this study. Descriptive statistics such as frequencies and means, as well as correlational (Pearson's correlation coefficient) were used to describe and analyze the research data. 


\section{FINDINGS}

\section{Philosophy of Adult Education}

A total of 399 questionnaires revealed that 28 educators were adopting liberalism, 66 behaviorism, 99 progressivism, 149 humanism and 57 radical theory as personal educational philosophy.

Table 1

Educational Philosophy (total)

\begin{tabular}{lll}
\hline Educational Philosophy & Frequency & Percent \\
\hline Liberalism & 28 & $7 \%$ \\
\hline Behaviorism & 66 & $16,5 \%$ \\
\hline Progressivism & 99 & $24,8 \%$ \\
\hline Humanism & 149 & $37,3 \%$ \\
\hline Radical theory & 57 & $14,3 \%$ \\
\hline Total & 399 & $100 \%$ \\
\hline
\end{tabular}

The following results do not concern all the questions in the questionnaire but those questions which concern the purpose of the training and the learning process. A total of 399 respondents revealed that $23(5.8 \%)$ adopted liberalism, $62(15.5 \%)$ behaviorism, $105(26.3 \%)$ progressivism, $137(34.3 \%)$ humanism and $72(18 \%)$ radical theory as personal educational philosophy in the learning process.

Table 2

Educational Philosophy in learning

\begin{tabular}{lll}
\hline Educational Philosophy in learning & Frequency & Percent \\
\hline Liberalism & 23 & $5,8 \%$ \\
\hline Behaviorism & 62 & $15,5 \%$ \\
\hline Progressivism & 105 & $26,3 \%$ \\
\hline Humanism & 137 & $34,3 \%$ \\
\hline Radical theory & 72 & $18,0 \%$ \\
\hline Total & 399 & $100 \%$ \\
\hline
\end{tabular}

Then the results follow which concern the teaching process. A total of 399 respondents revealed that 27 respondents $(6.8 \%)$ were liberalists, 54 (13.5\%) were behaviorists, 155 $(38.8 \%)$ were progressivists, $101(25.4 \%)$. humanitists and $62(15.5 \%)$ radicals in the teaching process.

Table 3

Educational Philosophy in teaching

\begin{tabular}{lll}
\hline Educational Philosophy in teaching & Frequency & Percent \\
\hline Liberalism & 27 & $6,8 \%$ \\
\hline Behaviorism & 54 & $13,5 \%$ \\
\hline Progressivism & 155 & $38,8 \%$ \\
\hline Humanism & 101 & $25,4 \%$ \\
\hline Radical theory & 62 & $15,5 \%$ \\
\hline Total & 399 & $100 \%$ \\
\hline
\end{tabular}


Correlation between personal educational philosophy and embracing educational philosophy in the learning process

For the correlation between the personal educational philosophy (generally) and the embracing educational philosophy in the learning process, the statistical test chi-square $\left(\mathrm{x}^{2}\right)$ was used, in order to identify any differences that exist in the distribution of the values of one variable in the values of the other, using the Pearson factor. As shown by the statistical test $\mathrm{x}^{2}$, the present null hypothesis $\left(\mathrm{H}_{0}\right)$ that these two variables are independent of each other is rejected $\left(\mathrm{x}^{2}(16, \mathrm{~N}=399)=438,417, p<0.01\right)$.

From the above it follows that the philosophical educational theory of each adult educator affects her/him in matters related to the learning process because most of the instructors who are included in a particular philosophical theory are included in the same theory and in these subjects, as shown by table below (Table 4).

The most important element for understanding and interpreting Table 4 is that we compare the frequencies on the columns and not the frequencies on the rows. The reason is that the frequencies on the rows are affected by the size of the groups that result from the categories of the variable. More specifically, out of the 28 adult educators who embrace liberalism as an educational philosophical theory, 11 embrace it in learning process. Something similar happens in the other theories, too. In the case of behaviorism this applies to 48 of the 66 educators, in the case of progressivism to 63 of the 99 , in the case of humanism to 100 of the 149 and finally, in terms of constructivism to 31 of the 57.

However, as can be seen from Table 4, there are cases where a significant number of participants, who in the learning process embrace a different educational philosophy than the one that they embrace generally. The most typical are the cases of progressivism and constructivism. In the first case, 17 and 12 instructors out of 99 adopt the humanist and constructivist educational philosophy, respectively. In percentage, this number corresponds to $26.7 \%$ of the total, which if it compared to those who embrace this educational philosophy in general, who are 63 , the $62.7 \%$ shows that there is a significant percentage of "progressists" educators who embrace more innovative educational theories in terms of learning process. Something similar happens in constructivism, where 17 trainers $(29.8 \%)$ embrace humanism. And this percentage, compared to the percentage of "purely" constructivists $(54.4 \%)$ is remarkable. Finally, it should be noticed that humanism precedes on issues related to the learning process because 137 educators adopt this theory, and that progressivism follows with little difference.

Table 4

Personal educational philosophy- Educational philosophy in learning process

\begin{tabular}{llllllll}
\hline & \multicolumn{7}{l}{ Personal educational philosophy } \\
\hline & & $\mathrm{L}$ & $\mathrm{B}$ & $\mathrm{P}$ & $\mathrm{H}$ & $\mathrm{C}$ & Total \\
\hline \multirow{4}{*}{$\begin{array}{l}\text { Educational } \\
\text { philosophy in } \\
\text { learning process }\end{array}$} & Liberalism (L) & 11 & 3 & 3 & 2 & 4 & 23 \\
\cline { 2 - 8 } & Behaviorism (B) & 6 & 48 & 4 & 3 & 1 & 62 \\
\cline { 2 - 8 } & Progressivism (P) & 7 & 9 & 63 & 22 & 4 & 105 \\
\cline { 2 - 8 } & Humanism (H) & 1 & 2 & 17 & 100 & 17 & 137 \\
\cline { 2 - 8 } & Constructivism (C) & 3 & 4 & 12 & 22 & 31 & 72 \\
\cline { 2 - 8 } & Total & 28 & 66 & 99 & 149 & 57 & 399 \\
\hline
\end{tabular}


Correlation between personal educational philosophy and embracing educational philosophy in the teaching process

For the correlation between the personal educational philosophy and the educational philosophy of the educator regarding the teaching process, the statistical test chi-square $\left(\mathrm{x}^{2}\right)$ was used again, in order to identify any differences that exist in the distribution of the values of one variable in the values of the other, using it Pearson factor. As shown by the statistical test $\mathrm{x}^{2}$, the present null hypothesis (H0) that these two variables are independent of each other is rejected $\left(\mathrm{x}^{2}(16, \mathrm{~N}=399)=595.677, p<0.01\right)$.

The above test shows that the philosophical educational theory of each adult educator affects her/ him in matters related to the teaching process because most of the participants who are included in a particular philosophical theory are included in the same theory and in teaching subjects, as shown by table below (Table 5). Comparing the columns in the table below (Table 5), 28 adult educators who embrace liberalism as a personal educational philosophy, 21 embrace it and apply its principles to the teaching process. Something similar happens in the other theories. In the case of behaviorism this is true for 46 of the 66 educators, in the case of progressivism for 77 of the 99 , in the case of humanism for 82 of the 149 and finally in terms of constructivism for 30 of the 57 trainers.

As can be seen from Table 5 and in the teaching process (as well as in the learning process) there are cases where a remarkable number of instructors, who embrace a specific educational philosophy in matters of teaching, integrate themselves into another. The case of humanism is more indicative. In particular, while the largest number of instructors 82 out of $149(55 \%)$ embrace humanism in general, there is a memorable number of 45 instructors who in the teaching process, embrace the theory of progressivism. Finally, it should be noted that the educational philosophy that gathers the largest number of educators in matters relating to the teaching process is progressivism, as 155 instructors in these subjects adopt this theory. Humanism is coming in second place with a small difference of 101 instructors.

It is recalled that in learning process humanism and progressivism have again been the dominant theories, but in reverse order as humanism has prevailed in learning.

Table 5

Personal educational philosophy- Educational philosophy in teaching process

\begin{tabular}{|c|c|c|c|c|c|c|c|}
\hline & & \multicolumn{6}{|c|}{ Personal educational philosophy } \\
\hline & & $\mathrm{L}$ & $\mathrm{B}$ & $\mathrm{P}$ & $\mathrm{H}$ & $\mathrm{C}$ & Total \\
\hline \multirow{6}{*}{$\begin{array}{l}\text { Educational } \\
\text { philosophy in } \\
\text { teaching process }\end{array}$} & Liberalism (L) & 21 & 2 & 1 & 1 & 2 & 27 \\
\hline & Behaviorism (B) & 0 & 46 & 5 & 3 & 0 & 54 \\
\hline & Progressivism $(\mathrm{P})$ & 3 & 15 & 77 & 45 & 15 & 155 \\
\hline & Humanism $(\mathrm{H})$ & 3 & 1 & 5 & 82 & 10 & 101 \\
\hline & Constructivism (C) & 1 & 2 & 11 & 18 & 30 & 62 \\
\hline & Total & 28 & 66 & 99 & 149 & 57 & 399 \\
\hline
\end{tabular}


Correlation between embracing educational philosophy in the learning process and embracing educational philosophy in the teaching process

For the correlation of the instructor's educational philosophy regarding the learning and teaching process, the chi-square test $\left(\mathrm{x}^{2}\right)$ was used again, in order to identify any differences in the distribution of the values of one variable in the values of the other, using the Pearson factor. As evidenced by the chi-square test $\left(\mathrm{x}^{2}\right)$, the present zero hypothesis $\left(\mathrm{H}_{0}\right)$ that these two variables are independent of each other is rejected $\left(\mathrm{x}^{2}=\right.$ $(16, \mathrm{~N}=399)=284.797, p<0.01)$. This fact indicates that the educational philosophy of each adult educator in learning process also influences her/ him in teaching process.

As can be seen from Table 6, there is a remarkable relation between these two variables as most of the instructors who embrace a particular theory in learning issues embrace it in the teaching process as well. There are cases, however, and it is worth noting that there is a "mobility" in trainers. More characteristic is the case of progressivism and humanism, where the differences in frequencies between them are minimal.

Table 6

Educational philosophy in learning process - Educational philosophy in teaching process

\begin{tabular}{llllllll}
\hline & & \multicolumn{3}{c}{ Educational philosophy in teaching process } \\
\hline & & $\mathrm{L}$ & $\mathrm{B}$ & $\mathrm{P}$ & $\mathrm{H}$ & $\mathrm{C}$ & \multicolumn{2}{c}{ Total } \\
\hline \multirow{4}{*}{$\begin{array}{l}\text { Educational } \\
\text { philosophy in } \\
\text { learning process }\end{array}$} & Liberalism (L) & 11 & 1 & 7 & 3 & 1 & 23 \\
\cline { 2 - 8 } & Behaviorism (B) & 5 & 40 & 12 & 3 & 2 & 62 \\
\cline { 2 - 8 } & Progressivism (P) & 8 & 8 & 57 & 11 & 21 & 155 \\
\cline { 2 - 8 } & Humanism (H) & 2 & 3 & 56 & 60 & 16 & 137 \\
\cline { 2 - 8 } & Constructivism (C) & 1 & 2 & 23 & 24 & 22 & 72 \\
\cline { 2 - 8 } & Total & 27 & 54 & 155 & 101 & 62 & 399 \\
\hline
\end{tabular}

\section{DISCUSSION}

It is clear from the findings of the research that educators who embrace the two most conservative theories, the liberalism and the behaviorism, are faithful to their views on the learning process with the philosophical theory they adopt in general. This is because learning process is the field that includes the basic "theoretical" principles of any educational philosophical theory (Broudy\& Palmer, 1965 Phillips\& Soltis, 1991). Therefore, it is logical and expected that people who embrace such theories in the learning process will be faithful to their theoretical principles, because these principles identify learning with the acquisition of knowledge and skills, and this is what they consider to be the purpose of learning. In contrary, in the other three educational theories, progressivism, humanism, and constructivism, which are distinguished by relativity, pluralism and a tendency to change, there is a mobility of instructors.

It is also worth noticed that humanism is the theory that dominates innovative theories (progressivism, humanism, and constructivism), because it aims to facilitate selfrealization and personal development (Merriam \& Brockett, 1997). The other two theories set, as the purpose of education, the transmission of social change and culture more focused on society (Elias \& Merriam, 1995). This shows that the educator as individual works more by seeing the learner as the target, and not society as a whole. So 
even if he belongs and integrates himself into another philosophical theory that is, of course, related to humanism in the learning process, they are more "focused" on the individual. It is also noteworthy that while humanism gathers the largest number of educators, no one who embraces liberalism and only one who embraces behaviorism would characterize himself as a humanist in the learning process. Once again this supports the conservatism and rigidity of these two theories.

About the teaching process, the case of humanism is more characteristic. In particular, while most educators embrace humanism, there are a significant number of 45 and 18 educators who in the teaching process embrace the theory of progressivism and constructivism, respectively. Finally, in this case, as well, it should be noted that the educational philosophical theory that gathers the largest number of instructors on issues related to the teaching process is progressivism, with humanism coming in second with a small difference.

Analyzing the above results, one can come to other conclusions. It is necessary to mention the small mobility of behaviorists and liberalists in other educational philosophical theories. The "rigidity" that prevails in these theories and the commitment to their principles will be emphasized once again. However, although the mobility is relatively small, educators direct towards student-centered theories. This situation shows the trend of the modern era in theories that are student-centered and renounce the authority of the educator (Kossivaki, 2003).

Another finding that needs to be emphasized and interpreted more is the fact that the greatest number of instructors are progressivists and not humanists as was the case with the correlation of the learning process. This is because humanism is judged as a selfcentered theory, in which each individual is responsible for himself. However, this cannot be in the teaching process, in which the instructor, the institutional framework, and the structure are hidden. In contrast, the progressivism gathers most educators because this philosophical theory is intertwined with adult education due to its focus on vocational training and scientific research (Gutek, 2004). Consequently, it is understandable because it gathers most of the trainers.

\section{CONCLUSION}

The five educational theories, liberalism, behaviorism, progressivism, humanism and constructivism were categorized into two groups based on their general principles (Elias $\&$ Merriam, 2005), in those that are more conservative and teacher-centered and in those that are more innovative and student-centered. The first category includes the first two theories (liberalism and behaviorism) and the other three belong to the student- centered category.

The results of the research are not, as one would expect, that adult educators reject the most conservative theories, liberalism and behaviorism, turning to the most innovative ones that deal more with the principles of adult learning, because they refer to autonomy, self-action and initiative on the part of the learner (Rothes et al., 2017). However, their superiority is clear $(75 \%$ are progressivists, humanists and constructivists). On the contrary, it is worthy to notice that while many instructors incorporate themselves into a conservative theory in terms of their teaching practices, 
they tend to the most innovative theories. The main share is absorbed by those of humanism and constructivism, with a percentage that exceeds $50 \%$.

It turns out that adult educators do not stick to an educational philosophical theory but prefer to combine elements from different ones (two or even three), a fact that Zinn herself (1983) had predicted. This combination is not necessarily in similar educational philosophical theories. Behaviorists adopt practices of constructivism, without implying that there is a "split" but instead there is a "combination". In fact, the practices applied by each adult educator are not a definitive statement of their inclusion in one educational philosophical theory, as they can change over time, depending on the circumstances or the goals. In addition, according to Apps (1973) it is an indication of a solid theoretical basis (when, of course, the educational philosophical theory was consciously chosen) as well as when they are familiar with the theory they advocate can and do maneuver since there are no barriers between theories. In fact, Brookfield (1990) argued for the need for flexibility to adapt to different educational philosophies with the aim of the more successful completion of educational process. Papastamatis (2010), also argues that the difference between a good adult educator and a mediocre one is that the former has a frame of reference for theoretical principles that allows her/ him to maneuver and teach creatively according to the needs of the trainees and the circumstances.

It is worth noting that the determination of the personal educational philosophy is not sufficient for resolving the problems modern adult educators have to face (Radovan, 2012). Evidently, the proper institutional arrangements, social and educational policies as well as a broader culture about adult learning should be in place. Taking into account all the above, the professional development of adult educators, due to the constant changes required by their role, has to be collaborative. Conferences and lectures should cease to be the only form of education and training for adult educators. However, in parallel with the trainings, their active participation is deemed necessary. It would be beneficial that the trainers participate in the design of the respective programs and in their implementation, as well as that cooperate with their colleagues, seeking their further improvement. At this point are added the self-assessment questionnaires, such as Zinn's PAEI, which give a very good stigma of the existing instructor training profile. In fact, in combination with the knowledge they have gained from training and their cooperation with other colleagues, they can get to know themselves better, so be able to develop. Nevertheless, being mindful of the kind of educational philosophy that underlies educational practices constitutes a clearly and undeniably necessary precondition for the adult educator's effective response to all modern challenges (Karavakou\& Papadima, 2015).

\section{REFERENCES}

Apps, J. W. (1973). Toward a working philosophy of adult education. Syracuse, NY: Syracuse University.

Bergevin, P. (1967). A philosophy for adult education. New York: The Seabury Press.

Boone, H.N., Gartin, S.A., Wright, C.B., Lawrence, L.D., \& Odell, K. (2002). Adult educational philosophies practiced by agricultural education teachers in Pennsylvania, Virginia and West Virginia. Journal of Agricultural Education, 43(3), pp.37-48. 
Brookfield, S. D. (1986). Understanding and facilitating adult learning, San Francisco: Jossey-Bass.

Brookfield, S. D. (1990). The skillful teacher: On technique, trust, and responsiveness in the classroom, San Francisco: Jossey-Bass.

Broudy, H. \& Palmer, J. (1965). Exemplars of teaching method. Chicago: Rand McNally,

Cervero, R. M. (1988). Effective continuing education for professionals. San Francisco: Jossey-Bass Publishers.

Collins, M. (1986). "Philosophy and the role of the adult educator", Paper presented at the Annual Meeting of the American Association for Adult and Continuing Education, Hollywood, FL. ERIC Document Reproduction Service No. ED277859.

Conti, J. G. (2007). Identifying your Educational Philosophy: Development of the Philosophies Held by Instructors of Lifelong-learners (PHIL). Journal of Adult Education, XXXXVI (1), pp. 19-37.

Conti, G. J. \& Fellenz, R. A. (1991). "Assessing adult learning strategies." In Proceedings of the 32nd adult education research conference (pp. 64-73). Norman, OK.

Dewey, J. (1956). The child and curriculum and the school and society. Chicago: University of Chicago Press.

Elias, J. L. \& Merriam, S. B. (1995). Philosophical foundations of adult education, $\left(2^{\text {nd }}\right.$ ed.), Malabar, FL: Krieger Publishing Company.

Fosnot, C. T. (1996a). "Constructivism: A psychological theory of learning". In C. T. Fosnot (Ed.), Constructivism: Theory, perspectives, and practice (pp. 8-33). New York: Teachers College Press.

Freire, P. (1985). The Politics of Education: Culture, power and liberation. South Hadley, MA: Bergin and Garvin.

Gagné, R.M. \& Medsker, K.L. (1996). The Conditions of Learning: Training Applications. Fort Worth: Harcourt Brace College Publishers.

Gergen, K.J. (1994) "The Social Constructivist Movement in Modern Psychology". American Psychologist, 40, 266-75.

George, D. \& Mallery, P. (2003). SPSS for Windows step by step: A simple guide and reference. 11.0 update (4th ed.). Boston, MA: Allyn \& Bacon.

Gutek, L. G. (2004). Philosophical and Ideological Voices in Education. United States of America: Pearson Education, Inc.

Higgs, P. \& Smith, J. (1997). Workbook for theoretical frameworks in Education. Study Guide 1 for ETH2O1N. Pretoria: University of South Africa.

Jarvis, P. (1985). The Sociology of Adult and Continuing Education, London \& New York: Routledge. 
Jarvis, P. (2005). International Dictionary of Adult and Continuing Education, London: Taylor\& Francis e-Library.

Jarvis, P., Griffin, C. (2003). Adult and Continuing Education: Major Themes in Education, London: Routledge.

Jarvis, P, Holford, J. \& Griffin, C. (2003). The theory \& practice of Learning, London: Taylor\& Francis e-Library.

Jerling, K. (1996). Onderwys, opleiding en ontwikkeling in organisasies. Pretoria: Kagiso.

Karavakou, V. \& Papadima, G. (2015). "Why do adult educators need to know their personal educational philosophy?", in Digital Proceedings from $3^{\text {rd }}$ International Symposium on New Issues on Teacher Education- ISNITE 2015, Volos: University of Thessaly Press.

Knowles, M. (1998). The adult learner: A neglected species (5th ed.). Houston, TX: Gulf Publishing Company.

Kossivaki, F. (2003). Alternative Didactics: Suggestions for Transitioning from the Teaching of the Subject to the Teaching of the Active Subject. Athens: Gutenberg. [in Greek]

Kumar, Ajay (2012). Philosophical Background of Adult and Lifelong Learning. $\begin{array}{lllll}\text { Retrieved April } & 10, & \text { from } & \end{array}$ http://www.unesco.org/education/paldin/pdf/unit03.pdf

Nunnally, J.C. \& Bernstein, I. H. (1994). Psychometric Theory, (3rdEd.). New York: McGraw-Hill

McKenzie, L. (1985). Philosophical orientation of adult educators. Lifelong Learning, 9(1), 18-20. (ERIC Document Reproduction Service No. EJ 320 691).

Merriam, S. B. (1986). The research to practice dilemma. Columbus, OH: ERIC Clearinghouse on Adult, Career, and Vocational Education. (ERIC Document Reproduction Service No. ED278801).

Merriam, S.B.\& Brockett, R.G. (1997). The Profession and Practice of Adult Education, San Francisco, Jossey- Bass.

Papadima, G. (2017). The importance of recognizing and exploiting philosophies of adult education: theoretical and empirical documentation. $\mathrm{PhD}$ Dissertation. http://dspace.lib.uom.gr/handle/2159/21845

Papadima, G. (2021). The Impact of Gender and Degree on The Adult Educator's Theoretical Identity. International Journal of Instruction, 14(2), 889-902. https://doi.org/10.29333/iji.2021.14250a

Papanaoum Z. (1994), “Adult educators: issues o professionalization”, in Benn R. \& Fieldhouse R. (eds), Training and professional development in Adult and Continuing Education, University of Exeter, Centre for Research in Continuing Education. 
Papastamatis, A. (2010). Adult Education: Foundations of Teaching Practice. Athens: Sideris. [in Greek].

Phillips, D.C. \& Soltis, J.F. (1991). Perspectives on learning, New York: Teachers Gollege Press.

Radovan, M. (2012). Understanding the Educational Barriers in Terms of the Bounded Agency Model. Journal of Contemporary Educational Studies, 63(129), 90-107.

Rodgers, R. F. (1980). Theories underlying student development. In D. G. Cramer (Ed.). Student development in higher education: Theories, practices, and future directions (27). Washington, D. C.: American College Personnel Association.

Rose, A. D. (2000). Philosophy is not a diagnosis. Adult Learning, 11(2), 20-22.

Rothes, A., Lemos, M. S., \& Gonçalves, T. (2017). Motivational profiles of adult learners. Adult Education Quarterly, 67(1), 3-29.

Schunk, D. H. (1996). Learning theories. Englewood Cliffs, NJ: Prentice-Hall, Inc.

Sener, J. (1997) Constructivism: Asynchronous Learning Networks. ALN Magazine, 1:1.

Skinner, B. F. (1971). Beyond Freedom and Dignity. New York: Knopf.

Van Doren, M. (1943). Liberal education. New York: Henry Holt \& Co.

Von Glasersfeld, E. (1984). "An introduction to radical constructivism", in Watzlawick, P (Ed), The Invented Reality, London, W.W. Naughton and Co.

Von Glasersfeld, E. (1987). "Learning as a constructive activity", in Janvier, C., Problems of representation in the teaching and learning of mathematics, New Jersey: Lawrence Erlbaum Associates, Inc., pp. 3-17.

Von Glasersfeld, E. (1989). "Constructivism in education", in Husen, T. \& Postlewaite, N. (Eds.), International Encyclopedia of Education [Suppl.], Oxford: Pergamon Press, pp.162-163.

Von Glasersfeld, E. (1995). "A constructivist approach to teaching", in Steffe, L. \& Gale, J. (Eds), Constructivism in Education, New Jersey: Lawrence Erlbaum Associates, Inc., pp.3-16.

Wang, V. (2003). Principles of adult education. Pearson Custom Publishing, Boston.

Zafiropoulos, K. (2012). Quantitative Empirical Research and Creation of Statistical Models. Athens: Kritiki (in Greek).

Zandvanian, A. (2009). Recognition and analysis of the educational philosophy of yarzd province adult education instructors. Proceedings of the 2nd International Conference of Teaching and Learning (ICTL 2009) INTI University College, Malaysia.

Zinn, L. M. (1983). Development of a valid and reliable instrument to identify a personal philosophy of adult education. Doctoral dissertation, Florida State. University.

Zinn, L. (1991). "Identifying Your Philosophical Orientation". In Knowles, M. Adult Learning Methods, Malabar, Florida: Krieger Publishing Company, pp. 39-78. 